\title{
Hydrochemical Assessment and Factor Analysis of Groundwater with Special Reference to Fluoride in Kanpur Dehat, U.P., India
}

\author{
${ }^{1}$ Neeraj Agnihotri, ${ }^{2}$ Vinay Kumar Pathak, ${ }^{3}$ Naseema Khatoon, \\ ${ }^{4}$ Masihur Rahman \\ ${ }^{1,2,3,4}$ Department of Industrial Chemistry, Integral University, Lucknow
}

\begin{abstract}
Present study aim to understand the hydrochemistry of underground water of Kanpur Dehat district U.P. with special reference to fluoride contamination. Total 75 samples from ground water sources scattered in 10 blocks of Kanpur Dehat were collected and analyzed statistically. The characteristic feature of ground water indicated the presence of $\mathrm{F}^{-}(0.20-4.76 \mathrm{mg} / \mathrm{L}), \mathrm{HCO}_{3}{ }^{2-}(213.50-1830.00 \mathrm{mg} / \mathrm{L}), \mathrm{CO}_{3}{ }^{2-}(0.00-204.00 \mathrm{mg} / \mathrm{L}) \mathrm{Cl}^{-}$ $(0.00-603.50 \mathrm{mg} / \mathrm{L}), \mathrm{SO}_{4}{ }^{2-}(1.92-649.00 \mathrm{mg} / \mathrm{L}), \mathrm{Mg}^{2+}(13.74-138.51 \mathrm{mg} / \mathrm{L}), \mathrm{Ca}^{2+}(3.21-93.23 \mathrm{mg} / \mathrm{L}), \mathrm{Na}^{+}(23.50-$ $750.00 \mathrm{mg} / \mathrm{L}$ ), $\mathrm{K}^{+}(2.00-87.12 \mathrm{mg} / \mathrm{L})$. In general $\mathrm{pH}$ of ground water is found to be alkaline (mean $\pm \mathrm{SD}$, 8.11 .0.40 with high value of EC (458.00-4992.00 $\mu \mathrm{S} / \mathrm{cm})$, TDS $(516.00-2998.00 \mathrm{mg} / \mathrm{L}), \mathrm{TH}(89.70-740.00$ $\mathrm{mg} / \mathrm{L})$, TA $(0.00-1500.00 \mathrm{mg} / \mathrm{L})$ and Iron $(0.00-419 \mathrm{mg} / \mathrm{L})$. Total $14.67 \%$ samples exceeds maximum desirable limit of BIS 10500 and WHO limit $(1.5 \mathrm{mg} / \mathrm{L})$. Sarwankhera is found to be worst affected where $50 \%$ samples exceeds both BIS maximum permissible limit and WHO limit, followed by Sandalpur, Derapur, Akbarpur, Rasulabad, Jhinjhank and Amroudha. Maitha, Rajpur and Malasa are found to be safe for drinking in reference of fluoride. The present study also revealed that fluoride enrichment in underground water is not ubiquitous, it occurs in patches. Some identified patched in present study area are Makanpur, Kakwan, Katra Aima, Mahua Derapur, Jalihapur, Hawaspur, Katra Bognipur, Vishayakpur and Rania. In Rania, which is an industrial area high fluoride contamination may be due anthropogenic activity. Fluoride shows significant strong positive correlation with EC $(r=0.326)$, TDS $(r=0.316), \mathrm{Na}^{+}(r=0.410), \mathrm{Cl}^{-}(\mathrm{r}=0.349)$ and $\mathrm{SO}_{4}^{2-}(\mathrm{r}=0.245)$. Strong significant negative correlation of fluoride is observed with TH $(r=-0.297), \mathrm{Ca}^{2+}(\mathrm{r}=-0.253)$ and $\mathrm{Mg}^{2+}(\mathrm{r}=-$ $0.223)$. Poor positive relation is observed with $\mathrm{pH}(\mathrm{r}=0.082)$, TA $(\mathrm{r}=0.065), \mathrm{K}^{+}(\mathrm{r}=0.045), \mathrm{HCO}_{3}{ }^{-}(\mathrm{r}=0.118)$ and poor negative correlation with $\mathrm{CO}_{3}{ }^{2-}(\mathrm{r}=-0.015)$ and $\mathrm{Fe}(\mathrm{r}=-0.020)$. In order to further investigate and identify contributing sources on the basis of chemical signatures, factor analysis of the data was done. The analysis yielded four dominant factors and was expressed by data matrix variance of $67.68 \%$.Present study advocate the fluoride enrichment of ground water is due to alkaline nature which led to increased sodium and bicarbonate concentration and decrease in calcium and magnesium concentration as a result of fluoride dissolution from fluoride bearing minerals.
\end{abstract}

Keywords: Correlation matrix, Factor analysis, Fluoride, Hydrochemistry, statistical analysis

\section{Introduction}

The occurrence of fluoride in ground water is mainly due to geogenic contamination of ground water and depends on the geological setting of an area ${ }^{1}$. The fluoride content of ground water is originate from the dissolution of fluoride bearing minerals in the bedrock and thus bedrock mineralogy is, in general plays a primary factor for the variations in fluoride content of ground water ${ }^{2}$. Many factors such as availability and solubility of fluorine-bearing minerals, temperature, $\mathrm{pH}$, concentration of calcium, bicarbonate and sodium ions in water, etc. plays important role in fluoride contamination of ground water. The excessive fluoride concentration in ground water may persist for very long time; enter into food chain, cause adverse impact on human health including dental or skeletal fluorosis etc. Therefore, it is essential to determine the causal factors of fluoride enrichment in underground water in time as space to mitigate the problem ${ }^{3}$.

In India at present at least 17 states are effected with high fluoride levels in ground water ranging from 0.5 to $50 \mathrm{mg} / \mathrm{L}^{4,5,6}$. The states of Andhra Pradesh, Punjab, Haryana, Rajasthan, Gujarat, Tamil Nadu, Kerala Madhya Pradesh Punjab, Bihar and Uttar Pradesh are seriously affected.

\section{Materials And Methods}

Kanpur Dehat is surrounded by districts Kanpur-Nagar, Hamirpur, Jalaun, Etawah, Kannauj and lying between $26^{\circ} \mathrm{N}$ to $25^{\circ} 55^{\prime} \mathrm{N}$ latitude and $79^{\circ} 30^{\prime} \mathrm{E}$ to $80^{\circ} \mathrm{E}$ longitude at AMSL - 471 feet. It has a population of 15.63 lakhs (as per 2001 census) in $3021 \mathrm{Sq} . \mathrm{Km}$. area. Rivers in Kanpur Dehat are; Isan, $16 \mathrm{Kms}$; Southern None, 26; Northern None, 55 Kms; Sengur, 63 Kms; Pandu, 30 Kms; Rind, 115 Kms. Kanpur Dehat has 05 Tehsils and 10 Development Blocks. There are 102 Nyay Panchayats and 612 Gram Sabhas in this district. 
Geologically, the area is entirely covered with Quaternary alluvium, overlying the concealed basement of Bundelkhand Granites and rocks of the Vindhyans Super Group. The study area is underlain by thick pile of unconsolidated Quaternary sediments comprising polycyclic sequence of silt, clay, sands of various grades with gravel and Kankar in varying proportions, forming a number of productive groundwater aquifers. The groundwater generally occurs in water table to semi-confined conditions.

Water samples were collected, in autoclaved pre-cleaned one litre sampling polyethylene container from 75 ground water sources (Shallow and pumps and India mark II hand pumps) scattered in the entire 10 blocks of Kanpur Dehat. Before taking final sample, the water was left to run from sampling source for 4-6 min to pump out the volume of water standing in casing.

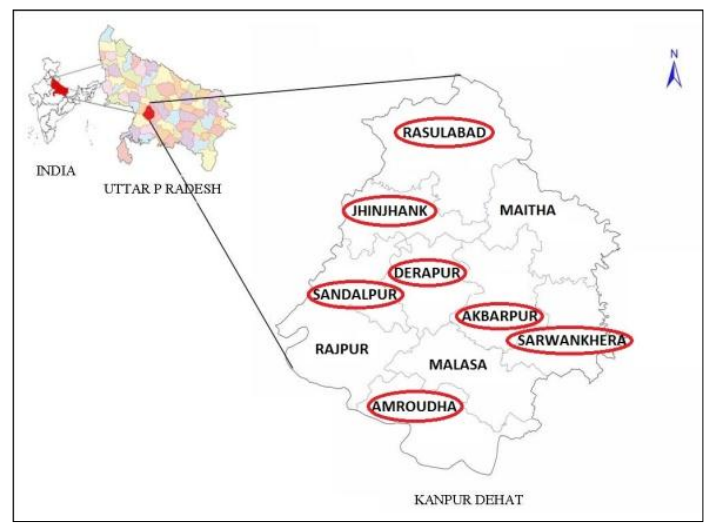

Fig 1: Location map of study area with fluoride distribution (The blocks encircled in red were found to contain high $\mathrm{F}^{-}$concentration)

Temperature and Total Dissolved Solids were analyzed with the help of TDS meter (SYMBON 205) during sample collection. $\mathrm{pH}$ was determined potentiometrically with the help of $\mathrm{pH}$ meter (Model: EUTECH Instruments $\mathrm{pH}$ 510) with glass reference electrode. Conductivity was measured by using Conductivity meter (Model: LABTRONICS LT 51).

All the chemicals used were of AR Grade (Fischer Scientific, India) and Milli-Q water (Millipore corp. with electrical resistivity of $18.2 \mathrm{M} \Omega \mathrm{cm}$ ) was used for preparation of solution and dilution purposes.

Fluoride concentration was determined by the SPADNS colorimetric method and other parameters such as Total hardness ( $\mathrm{TH}$ as $\mathrm{CaCO}_{3}$ ) $, \mathrm{Ca}^{2+}, \mathrm{Mg}^{2+}, \mathrm{Na}^{+}, \mathrm{K}^{+}, \mathrm{CO}_{3}{ }^{2-}, \mathrm{HCO}_{3}{ }^{-}, \mathrm{SO}_{4}{ }^{2-}, \mathrm{Cl}^{-}$, Total alkalinity (TA), Iron were determined by standard methods ${ }^{7}$. All the experiments were carried out thrice and results were found reproducible within $\pm 3 \%$ error limit.

Statistical characterization of data and correlation matrix (Pearson's correlation) was analyzed using SPSS 17.0 (Version 17.0.1). Factor analysis was carried out using XLSTAT (Version 2013.5.06). Factor analysis using varimax rotation method was applied for only those factors whose Eigen values are greater than one were retained (Kaiser Normalisation).

\section{Results And Discussions}

Total 75 samples were collected and analyzed from 10 blocks of Kanpur Dehat and summary of fluoride is given in table no. 1. Descriptive statistics of each hydrochemical parameter are given in table no.2 which also reflects the desirable limit prescribed according to WHO guidelines and BIS: 10500.

\begin{tabular}{|c|c|c|c|c|c|c|c|}
\hline \multicolumn{8}{|c|}{ Table1: Summary of fluoride of the samples of Kanpur Dehat, Uttar Pradesh } \\
\hline \multirow{2}{*}{ Blocks } & \multicolumn{2}{|c|}{ Location } & \multirow{2}{*}{$\mathrm{N}$} & \multicolumn{3}{|c|}{ Fluoride in $\mathrm{mg} / \mathrm{L}$} & \multirow{2}{*}{$\begin{array}{c}\text { Percentage of } \\
\text { Samples } \geq 1.5 \\
\text { mg/L* }\end{array}$} \\
\hline & Latitude & Longitude & & Min. & Max. & Mean \pm SD & \\
\hline Rasulabad & $26^{\circ} 40^{\prime} \mathrm{N}$ & $79^{\circ} 46^{\prime} \mathrm{E}$ & 11 & 0.24 & 3.25 & $0.92 \pm 0.88$ & 18.18 \\
\hline Maitha & $26^{\circ} 31^{\prime} \mathrm{N}$ & $80^{\circ} 3^{\prime} \mathrm{E}$ & 7 & 0.42 & 0.84 & $0.55 \pm 0.16$ & NIL \\
\hline Akabarpur & $26^{\circ} 22^{\prime} \mathrm{N}$ & $79^{\circ} 56^{\prime} \mathrm{E}$ & 8 & 0.20 & 1.63 & $0.74 \pm 0.46$ & 12.50 \\
\hline Derapur & $26^{\circ} 25^{\prime} \mathrm{N}$ & $79^{\circ} 47^{\prime} \mathrm{E}$ & 8 & 0.30 & 1.79 & $0.83 \pm 0.55$ & 25.00 \\
\hline Jhinjhank & $26^{\circ} 33^{\prime} \mathrm{N}$ & $79^{\circ} 44^{\prime} \mathrm{E}$ & 7 & 0.43 & 4.76 & $1.18 \pm 1.58$ & 14.29 \\
\hline Sandalpur & $26^{\circ} 25^{\prime} \mathrm{N}$ & $79^{\circ} 40^{\prime} \mathrm{E}$ & 4 & 0.37 & 2.30 & $0.92 \pm 0.92$ & 25.00 \\
\hline Rajpur & $26^{\circ} 35^{\prime} \mathrm{N}$ & $79^{\circ} 41^{\prime} \mathrm{E}$ & 7 & 0.22 & 0.53 & $0.41 \pm 0.10$ & NIL \\
\hline Malasa & $26^{\circ} 16^{\prime} \mathrm{N}$ & $79^{\circ} 57^{\prime} \mathrm{E}$ & 6 & 0.34 & 0.56 & $0.44 \pm 0.08$ & NIL \\
\hline Amroudha & $26^{\circ} 11^{\prime} \mathrm{N}$ & $79^{\circ} 46^{\prime} \mathrm{E}$ & 11 & 0.20 & 1.65 & $0.57 \pm 0.37$ & 9.09 \\
\hline Sarwankhera & $26^{\circ} 23^{\prime} \mathrm{N}$ & $79^{\circ} 52^{\prime} \mathrm{E}$ & 6 & 0.27 & 4.65 & $1.47 \pm 1.68$ & 50.00 \\
\hline TOTAL & & & 75 & 0.2 & 4.76 & 0.83 & 14.67 \\
\hline
\end{tabular}




\begin{tabular}{|c|c|c|c|c|c|c|c|c|c|c|c|c|c|c|c|}
\hline \multicolumn{16}{|c|}{ Table2: Summarized hydrochemical analysis of 75 samples from Kanpur Dehat, UP } \\
\hline Statistics & pH & EC & TDS & TH & TA & $\mathbf{F e}$ & $\mathrm{Ca}^{2+}$ & $\mathbf{M g}^{2+}$ & $\mathrm{Na}^{+}$ & $\mathbf{K}^{+}$ & $\mathrm{HCO}_{3}^{-}$ & $\mathrm{CO}_{3}^{2-}$ & $\mathrm{Cl}^{-}$ & $\mathbf{S O}_{4}{ }^{2-}$ & $\mathbf{F}^{-}$ \\
\hline Parameters & & & & & & & & & & & & & & & \\
\hline Minimum & 7.03 & 858.00 & 516.00 & 89.70 & 0.00 & 0.00 & 3.21 & 13.74 & 23.50 & 2.00 & 213.50 & 0.00 & 0.00 & 1.92 & 0.20 \\
\hline Maximum & 9.00 & 4992.00 & 2998.00 & 740.00 & 1500.00 & 419.00 & 93.23 & 138.51 & 750.00 & 87.12 & 1830.00 & 204.00 & 603.50 & 649.00 & $4.76^{*}$ \\
\hline Range & 1.97 & 4134.00 & 2482.00 & 650.30 & 1500.00 & 419.00 & 90.02 & 124.77 & 726.50 & 85.12 & 1616.50 & 204.00 & 603.50 & 647.08 & 4.56 \\
\hline Mean & 8.11 & \begin{tabular}{|l|}
1707.01 \\
\end{tabular} & \begin{tabular}{|l|}
1039.07 \\
\end{tabular} & 309.37 & \begin{tabular}{|l|}
402.69 \\
\end{tabular} & \begin{tabular}{|l|}
6.24 \\
\end{tabular} & 31.33 & 56.21 & $\mid 175.83$ & 12.42 & \begin{tabular}{|l|}
507.79 \\
\end{tabular} & \begin{tabular}{|l|}
14.40 \\
\end{tabular} & 86.42 & 141.10 & 0.79 \\
\hline Median & 8.06 & 1412.00 & \begin{tabular}{|l|}
858.00 \\
\end{tabular} & 290.00 & 390.00 & 0.38 & 27.87 & 52.97 & 133.32 & \begin{tabular}{|l|}
6.37 \\
\end{tabular} & 475.80 & 0.00 & 24.99 & 94.08 & 0.51 \\
\hline S.D. & 0.40 & 840.68 & 509.33 & 115.75 & 194.29 & 48.31 & \begin{tabular}{|l|}
19.87 \\
\end{tabular} & 24.12 & 160.35 & 17.36 & 228.40 & 34.90 & 136.88 & 133.85 & 0.83 \\
\hline SEM & 0.05 & 97.07 & 58.81 & 13.37 & 22.43 & 5.58 & 2.29 & 2.79 & 18.52 & 2.00 & 26.37 & 4.03 & 15.81 & 15.46 & 0.10 \\
\hline \begin{tabular}{|l|} 
WHO \\
Standards
\end{tabular} & $6.5-8.5$ & NG & 500 & 500 & NG & 0.30 & 75 & 50 & 200 & NG & NG & NG & 250 & 250 & 1.5 \\
\hline BIS 10500 & $6.5-8.5$ & NG & 500 & 300 & 200 & 0.30 & 75 & 30 & 200 & NG & NG & NG & 250 & 250 & 1.5 \\
\hline
\end{tabular}

In general $\mathrm{pH}$ of ground water is found to be alkaline (range, 7.03-9.00; mean $\pm \mathrm{SD}, 8.11 \pm 0.40$ ), $16 \%$ of total samples contain $\mathrm{pH}$ more than 8.5 and the highest value of $\mathrm{pH} 9.0$ was found in Vishayakpur, Sarwankhera Block. Study area contains high value of EC (range, 858.00-4992.00 $\mu \mathrm{S} / \mathrm{cm}$; mean \pm SD, 1707.01 \pm 840.68 ), TDS (range, 516.00-2998.00 mg/L; mean \pm SD, 1039.07 \pm 509.33 ), TH (range, 89.70-740.00 $\mathrm{mg} / \mathrm{L}$; mean $\pm \mathrm{SD}, 309.37 \pm 115.75$ ), TA (range, $0.00-1500.00 \mathrm{mg} / \mathrm{L}$; mean $\pm \mathrm{SD}, 402.69 \pm 194.29$ ) and Iron (range, 0.00-419 mg/L; mean $\pm \mathrm{SD}, 6.24 \pm 48.31$ ).

Among anions, $\mathrm{HCO}_{3}{ }^{2-}$ (range, 213.50-1830.00 mg/L; mean $\pm \mathrm{SD}, 507.79 \pm 228.40$ ) is present in higher concentration whereas $\mathrm{CO}_{3}{ }^{2-}$ (range, $0.00-204.00 \mathrm{mg} / \mathrm{L}$; mean $\pm \mathrm{SD}, 14.40 \pm 34.90$ ), $\mathrm{Cl}^{-}$(range, 0.00-603.50 $\mathrm{mg} / \mathrm{L}$; mean $\pm \mathrm{SD}, 86.42 \pm 136.88), \mathrm{SO}_{4}{ }^{2-}$ (range, $1.92-649 \mathrm{mg} / \mathrm{L}$; mean $\left.\pm \mathrm{SD}, 141.10 \pm 133.85\right), \mathrm{F}^{-}$(range 0.20$4.76 \mathrm{mg} / \mathrm{L}$; mean $\pm \mathrm{SD}, 0.79 \pm 0.83)$ are present in low to moderate concentrations.

Among cations, $\mathrm{Mg}^{2+}$ (range, 13.74-138.51 mg/L; mean $\pm \mathrm{SD}, 56.21 \pm 24.21$ ) is present in higher concentration whereas $\mathrm{Ca}^{2+}$ (range, 3.21-93.23 mg/L; mean $\pm \mathrm{SD}, 31.33 \pm 19.87$ ), $\mathrm{Na}^{+}$(range, 23.50-750.00 $\mathrm{mg} / \mathrm{L}$; mean $\pm \mathrm{SD}, 175.83 \pm 160.35), \mathrm{K}^{+}$(range, $2.00-87.12 \mathrm{mg} / \mathrm{L}$; mean $\pm \mathrm{SD}, 12.42 \pm 17.36$ ) are present on moderate concentrations. The above values are in close agreement of earlier researchers $8,9,10,11$.

On the basis of extensive analysis it was found that total $14.65 \%$ samples exceeds maximum desirable limit of BIS 10500 and WHO limit $(1.5 \mathrm{mg} / \mathrm{L})$. Sarwankhera is found to be worst affected where $50 \%$ samples exceeds both BIS maximum permissible limit and WHO limit, followed by Sandalpur, Derapur, Akbarpur, Rasulabad, Jhinjhank and Amroudha. Maitha, Rajpur and Malasa are found to be safe for drinking in reference of fluoride. The present study also revealed that fluoride enrichment in underground water is not ubiquitous, it occurs in patches. Some identified patched in present study area are Makanpur, Kakwan, Katra Aima, Mahua Derapur, Jalihapur, Hawaspur, Katra Bognipur, Vishayakpur and Rania. In Rania, which is an industrial area high fluoride contamination may be due anthropogenic activity.

To examine the relationships of $\mathrm{F}^{-}$with other hydrochemical parameters, correlation matrix (Table 3) has been generated for derived parameters of groundwater samples. Fluoride shows significant strong positive correlation with EC $(r=0.326)$, TDS $(r=0.316), \mathrm{Na}^{+}(r=0.410), \mathrm{Cl}^{-}(\mathrm{r}=0.349)$ and $\mathrm{SO}_{4}{ }^{2-}(\mathrm{r}=0.245)$. Strong significant negative correlation of fluoride is observed with TH $(\mathrm{r}=-0.297), \mathrm{Ca}^{2+}(\mathrm{r}=-0.253)$ and $\mathrm{Mg}^{2+}(\mathrm{r}=-$ $0.223)$. Weak positive relation is observed with $\mathrm{pH}(\mathrm{r}=0.082)$, TA $(\mathrm{r}=0.065), \mathrm{K}^{+}(\mathrm{r}=0.045), \mathrm{HCO}_{3}{ }^{-}(\mathrm{r}=$ $0.118)$ and weak negative correlation with $\mathrm{CO}_{3}{ }^{2-}(\mathrm{r}=-0.015)$ and $\mathrm{Fe}(\mathrm{r}=-0.020)$.

The above mentioned observation suggests that an increase in $\mathrm{Na}^{+}$concentration in groundwater is associated with increase in $\mathrm{F}^{-}$concentration with increase in bicarbonate as reported by earlier researcher ${ }^{12}$. According to Apambire et al. (1997) $)^{13}$, anion exchange $\left(\mathrm{OH}^{-}\right.$for $\left.\mathrm{F}^{-}\right)$is the dominant process in the sedimentary basin which leads to base exchange $\left(\mathrm{Na}^{+}\right.$for $\mathrm{Ca}^{2+}$ and $\left.\mathrm{Mg}^{2+}\right)$ resulting in an increase in $\mathrm{Na}^{+}$content and decrease in $\mathrm{Ca}^{+}$and $\mathrm{Mg}^{+}$content. Further, the fact that high concentration of $\mathrm{Na}^{+}$increases the solubility of $\mathrm{F}^{-}$bearing minerals explains the enrichment in $\mathrm{F}^{-}$concentration with increase in $\mathrm{Na}^{+}$content in groundwater of the study $\operatorname{area}^{13,14}$. 
Table 3: Correlation matrix of hydrochemical parameters of ground water samples from different blocks of Kanpur Dehat, UP

\begin{tabular}{|c|c|c|c|c|c|c|c|c|c|c|c|c|c|c|}
\hline & $\mathrm{EC}$ & $\mathrm{TDS}$ & $\mathrm{TH}$ & $\mathrm{TA}$ & $\mathrm{Ca}^{2+}$ & $\mathrm{Mg}^{2+}$ & $\mathrm{Na}^{+}$ & $\mathrm{K}^{+}$ & $\mathrm{HCO}_{3}$ & $\mathrm{CO}_{3}^{2-}$ & $\mathrm{Cl}^{-}$ & $\mathrm{SO}_{4}^{2-}$ & $\mathrm{F}^{-}$ & $\mathrm{Fe}$ \\
\hline $\mathrm{pH}$ & 0.118 & 0.126 & -0.123 & 0.105 & $-0.355^{* *}$ & 0.036 & 0.154 & -0.116 & 0.072 & $0.500^{* *}$ & 0.087 & -0.009 & 0.082 & 0.099 \\
\hline $\mathrm{EC}$ & 1 & $0.990^{* *}$ & 0.031 & $0.686^{* *}$ & 0.040 & 0.018 & $0.950^{* *}$ & $0.306^{* *}$ & $0.693^{* *}$ & 0.158 & $0.688^{* *}$ & $0.659^{* *}$ & $0.326^{* *}$ & 0.022 \\
\hline $\mathrm{TDS}$ & & 1 & 0.001 & $0.686^{* *}$ & 0.022 & -0.008 & $0.952^{* *}$ & $0.294^{*}$ & $0.706^{* *}$ & 0.184 & $0.667^{* *}$ & $0.639^{* *}$ & $0.316^{* *}$ & 0.157 \\
\hline $\mathrm{TH}$ & & & 1 & 0.087 & $0.524^{* *}$ & $0.905^{* *}$ & $-0.250^{*}$ & 0.144 & 0.028 & -0.181 & 0.077 & 0.049 & $-0.297^{* *}$ & -0.212 \\
\hline $\mathrm{TA}$ & & & & 1 & 0.074 & 0.067 & $0.592^{* *}$ & 0.203 & $0.937^{* *}$ & $0.308^{* *}$ & 0.095 & 0.068 & 0.065 & 0.124 \\
\hline $\mathrm{Ca}^{2+}$ & & & & & 1 & 0.111 & -0.098 & $0.348^{* *}$ & 0.045 & $-0.398^{* *}$ & 0.102 & -0.041 & $-0.253^{*}$ & -0.139 \\
\hline $\mathrm{Mg}^{2+}$ & & & & & & 1 & $-0.241^{*}$ & -0.006 & 0.012 & -0.008 & 0.041 & 0.077 & -0.223 & -0.178 \\
\hline $\mathrm{Na}^{+}$ & & & & & & & 1 & 0.206 & $0.608^{* *}$ & 0.202 & $0.698^{* *}$ & $0.622^{* *}$ & $0.410^{* *}$ & 0.106 \\
\hline $\mathrm{K}^{+}$ & & & & & & & & 1 & 0.215 & -0.129 & 0.148 & $0.236^{*}$ & 0.045 & -0.055 \\
\hline $\mathrm{HCO}_{3}{ }^{-2}$ & & & & & & & & 1 & 0.192 & 0.054 & 0.057 & 0.118 & 0.156 \\
\hline $\mathrm{CO}_{3}^{2-}$ & & & & & & & & & & 1 & -0.042 & -0.077 & -0.015 & $0.233^{*}$ \\
\hline $\mathrm{Cl}^{-}$ & & & & & & & & & & & 1 & $0.598^{* *}$ & $0.349^{* *}$ & -0.066 \\
\hline $\mathrm{SO}_{4}{ }^{2-}$ & & & & & & & & & & & & 1 & $0.245^{*}$ & -0.086 \\
\hline $\mathrm{F}^{-}$ & & & & & & & & & & & & & 1 & -0.020 \\
\hline $\mathrm{Fe}$ & & & & & & & & & & & & & 1 \\
\hline
\end{tabular}

In order to further investigate and identify contributing sources on the basis of chemical signatures, factor analysis of the data was done. The analysis yielded four dominant factors and was expressed by data matrix variance of $67.68 \%$. Factor loading is classified as 'strong', 'moderate', and 'weak' corresponding to absolute loading values (positive or negative) of $>0.75,0.75-0.50$ and $0.50-0.30$ respectively. Component loadings of principle components is shown in figure 2 .

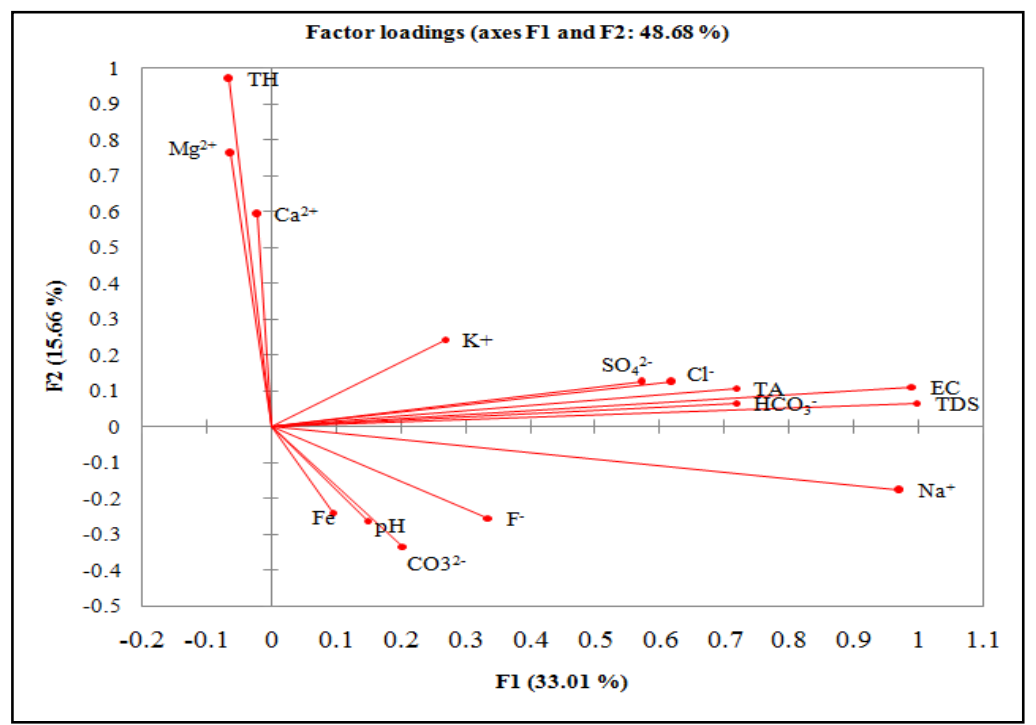

Figure 2: Factor loadings (axes F1 and F2: $48.67 \%$ ) of different hydrochemical parameters $(\mathrm{N}=75)$

Factor I explains $33.01 \%$ of total variance showing loadings of EC, TDS, TA, $\mathrm{Na}^{+}, \mathrm{K}^{+}, \mathrm{HCO}_{3}^{-}, \mathrm{Cl}^{-}, \mathrm{SO}_{4}{ }^{2-}, \mathrm{F}^{-}$. Factor shows the strong loading of EC, TDS and $\mathrm{Na}^{+}$, moderate loading of $\mathrm{TA}, \mathrm{Cl}^{-}, \mathrm{SO}_{4}{ }^{2-}$ and $\mathrm{HCO}_{3}{ }^{-}$and weak loading of $\mathrm{F}^{-}$and $\mathrm{K}^{+}$. The combination of these factors represents the dissolved ion load of ground water. Besides $\mathrm{Na}^{+}, \mathrm{Cl}^{-}, \mathrm{SO}_{4}{ }^{2-}$ and $\mathrm{HCO}_{3}^{-}, \mathrm{F}^{-}$, however, to the some extent, also contributes to the ion load of ground water.

Factor II, explains $15.66 \%$ of total variance. Strong positive loading between total hardness, $\mathrm{Mg}^{+2}$ and $\mathrm{Ca}^{+2}$ shows that $\mathrm{Mg}^{+2}$ and $\mathrm{Ca}^{+2}$ contribute to the total hardness. However the total hardness may be due to $\mathrm{Mg}^{+2}$.

Factor III, explains the $11.12 \%$ of total variance. None of the parameters shows any significance between themselves. 
Factor IV, explains the $7.88 \%$ of total variance. Significant correlation between carbonate and $\mathrm{pH}$ shows that $\mathrm{CO}_{3}{ }^{2-}$ is present in some samples due to increased $\mathrm{pH}$.

Table 4: Factor loadings of different chemical parameters of groundwater samples $(\mathrm{N}=75)$ from the study area (significant loadings marked in bold).

\begin{tabular}{|c|c|c|c|c|}
\hline & F1 & F2 & F3 & F4 \\
\hline pH & 0.150 & -0.263 & -0.212 & 0.469 \\
\hline $\mathrm{EC}(\boldsymbol{\mu s} / \mathrm{cm})$ & 0.991 & 0.110 & 0.077 & 0.026 \\
\hline TDS mg/L & 0.997 & 0.065 & 0.040 & 0.021 \\
\hline TH (mg/L) & -0.064 & 0.968 & -0.120 & 0.210 \\
\hline TA (mg/L) & 0.717 & 0.107 & -0.620 & -0.189 \\
\hline $\mathrm{Ca}^{2+}(\mathrm{mg} / \mathrm{L})$ & -0.020 & 0.591 & 0.097 & -0.463 \\
\hline $\mathrm{Mg}^{2+}(\mathrm{mg} / \mathrm{L})$ & -0.061 & 0.760 & -0.193 & 0.516 \\
\hline $\mathrm{Na}^{+}(\mathrm{mg} / \mathrm{L})$ & 0.971 & -0.178 & 0.160 & 0.000 \\
\hline $\mathbf{K}^{+}(\mathbf{m g} / \mathbf{L})$ & 0.269 & 0.242 & 0.089 & -0.261 \\
\hline $\mathrm{HCO}_{3}{ }^{-}(\mathrm{mg} / \mathrm{L})$ & 0.718 & 0.065 & -0.582 & -0.275 \\
\hline $\mathrm{CO}_{3}{ }^{2-}(\mathrm{mg} / \mathrm{L})$ & 0.205 & -0.333 & -0.430 & 0.431 \\
\hline $\mathrm{Cl}^{-}(\mathrm{mg} / \mathrm{L})$ & 0.619 & 0.124 & 0.520 & 0.194 \\
\hline $\mathrm{SO}_{4}{ }^{2-}(\mathrm{mg} / \mathrm{L})$ & 0.571 & 0.124 & 0.494 & 0.174 \\
\hline $\mathrm{F}^{-}(\mathrm{mg} / \mathrm{L})$ & 0.337 & -0.255 & 0.244 & 0.042 \\
\hline $\mathrm{Fe}(\mathrm{mg} / \mathrm{L})$ & 0.095 & -0.240 & -0.195 & -0.003 \\
\hline Eigenvalue & 4.952 & 2.349 & 1.668 & 1.182 \\
\hline Variability (\%) & 33.014 & 15.662 & 11.121 & 7.881 \\
\hline Cumulative \% & 33.014 & 48.676 & 59.796 & 67.677 \\
\hline
\end{tabular}

\section{Conclusions}

The presence of fluoride in ground water cannot be predicted due to its sporadic occurrence which is also observed in present study. Presence of fluoride in ground water is often recognized only when people exhibit symptoms of fluorosis. Therefore there is an intense need of developing measures to prevent and cure ground water quality through water quality analysis and study of spatial distribution to identify sources, causes, type and level of fluoride contamination. To know hydro-geochemical control in relation to aquifer character isotope studies may be taken up for aquifer mapping to delineate the fluoride rich pockets and artificial flushing of identified aquifer to reduce fluoride concentration.

\section{References}

[1] Saxena, V.K. and Ahmed, S., 2001. Dissolution of fluoride in groundwater: a water rock interaction study. Environmental Geology, (40)9(9): 1084-1087.

[2] Chae, G.Y., Seong, T.M., Bernhard, K., Kyoung-Ho, K. and Seong-Yong, K., 2007. Fluorine geochemistry in bedrock groundwater of South Korea. Science of The Total Environment, 385(1-3): 272-283.

[3] Ahmed, S., Bertrand, F., Saxena, V., Subramaniyam, K. and Touchard, F., 2002. A geostatistical method of determining priority of measurement wells in a fluoride monitoring network in an aquifer. Journel of applied Geochem, 4(2B): 576-585.

[4] WHO, 2006. Fluoride in drinking water.

[5] IS 11624:1986, "Guidelines for the quality of irrigation water", Bureau of Indian Standards, New Delhi, 1986. IS 10500:1991, "Drinking water", Bureau of Indian Standards, New Delhi, 1991, p.g. 8

[6] WHO, "Guidelines for drinking water quality ( $3^{\text {rd }}$ edition) Vol I: Recommendations, World Health Organisation Geneva, 2004, p.366.

[7] APHA, AWWA, WPCF. Standard Methods for Examination of Water and Wastewater, 21 th edition, Washington, D.C, (2005).

[8] Pandey C. K., Faruqi, N. H., and Nagar, M. (1990) Geoenvironmental appraisal of Ganga Basin, Uttar Pradesh, Unpublished Progress Report, G.S.I

[9] Faruqi, N. H.(2002) Final report on Geoenvironmental appraisal of Unnao district, Uttar Pradesh. Unpublished Progress Report, GSI, (F. S. 1997-98 and 1998-99)

[10] Faruqi, N. H.(2002) Report on Geoenvironmental appraisal of Kanpur Nagar and Kanpur Dehat districts, Uttar Pradesh. (F. S. 1995 96, 1996-97) Unpublished Progress Report, GSI

[11] S.K.Kar (2004-2005) Geological And Hydrogeochemical Control Of Fluoride Distribution In Ground Water In Parts Of Central Ganga Plain, Uttar Pradesh (F. S. 2004-05)

[12] Handa, B.K., 1975. Geochemistry and genesis of fluoride containing groundwater in India. Groundwater, 13: 275-81.

[13] Apambire, W.B., Boyle, D.R. and Michel, F.A., 1997. Geochemistry, genesis and health implication of fluoriferous groundwater in the upper regions, Ghana. Environ Geology, 33: 13-24

[14] Guo, Q., Wang, Y., Ma, T. and Ma, R., 2007. Geochemical processes controlling the elevated fluoride concentrations in groundwater of the Taiyuan Basin, Northern China. Journal of Geochemical Exploration, 93(1): 1-12. 